\begin{tabular}{cc|c}
\hline Tar. Bil. Der. & Journal of Agricultural Sciences \\
& $\begin{array}{c}\text { Dergi web sayfası: } \\
\text { www.agri.ankara.edu.tr/dergi }\end{array}$ & Journal homepage: \\
& www.agri.ankara.edu.tr/journal
\end{tabular}

\title{
Determination of Stomatal Density and Distribution on Leaves of Turkish Hazelnut (Corylus avellana L.) Cultivars
}

\author{
Nurten AVCI ${ }^{a}$, Ahmet AYGÜN ${ }^{b}$ \\ ${ }^{a}$ Ordu Ziraat Odast,52100 Ordu, TURKEY \\ ${ }^{\boldsymbol{b}}$ Ordu Üniversitesi, Ziraat Fakültesi, Bahçe Bitkileri Bölümü, 52200, Ordu, TURKEY
}

\section{ARTICAL INFO}

Research Article

DOI: 10.1501/Tarimbil 0000001304

Corresponding Author: Ahmet AYGÜN, E-mail: ayguna70@hotmail.com, Tel: +90 (452) 2265226

Received: 09 June 2014, Received in Revised Form: 12 August 2014, Accepted: 03 September 2014

\begin{abstract}
This study was carried out to determine stomatal distribution and density in leaves of 18 Turkish hazelnut cultivars. Stomata were detected only on the lower leaf surface (hypostomatous). The number of stomata varied between 83.08 (Kalınkara) and 117.73 (Sivri) per $\mathrm{mm}^{2}$. The length and the width of stoma in the cultivars were within the ranges of 22.00-27.45 $\mu \mathrm{m}$ and 17.00-22.61 $\mu \mathrm{m}$, respectively. The longest and the widest stoma were measured in Yass 1 Badem. Among the cultivars, Sivri had the highest stoma index (17.15\%) while Kalınkara had the lowest (10.55\%). The number of epidermal cells varied between 567 and 681 per $\mathrm{mm}^{2}$. There were negative correlations for number of stomata with the stoma length $(-0.407)$ and with stoma width $(-0.380)$. The results showed that hazelnut cultivars have a unique stoma features which might be important in varietal identification.
\end{abstract}

Keywords: Hazelnut; Stoma; Stomatal density; Stoma index

\section{Türk Fındık (Corylus avellana L.) Çeşitlerinin Yapraklarında Stoma Yoğunluğu ve Dağılımının Belirlenmesi}

\section{ESER BILGİí}

Araştırma Makalesi

Sorumlu yazar: Ahmet AYGÜN, E-posta: ayguna70@hotmail.com, Tel: +90 (452) 2265226

Geliş tarihi: 09 Haziran 2014, Düzeltmelerin gelişi: 12 Ağustos 2014, Kabul: 03 Eylül 2014

\begin{abstract}
ÖZET
Bu çalışmada, 18 Türk findık çeşidinin yapraklardaki stoma sayısı ve dağılımı incelenmiştir. Stomalar yalnızca yaprakların alt yüzeyinde gözlenmiştir (hipostomatik). Yapraklardaki stoma sayısı 83.08 (Kalınkara) - 117.73 (Sivri) adet $/ \mathrm{mm}^{2}$ arasında değişmiştir. Stoma boyu 22.00-27.45 $\mu \mathrm{m}$ arasında ve stoma eni 17.00-22.61 $\mu \mathrm{m}$ arasında ölçülmüş̧ür. Stoma boyu ve stoma eni bakımından en yüksek değerler Yassı Badem çeşidinde tespit edilmiştir. Stoma indeksi en yüksek Sivri (\% 17.15) ve en düşük Kalınkara (\% 10.55) çeşitlerinde belirlenmiştir. Yapraklardaki epidermis hücre sayısı çeşitlere göre 567-681 adet $/ \mathrm{mm}^{2}$ arasında değişmiştir. Stoma sayısı ile stoma boyu $(-0.407)$ ve eni $(-0.380)$ arasında negatif korelasyon belirlenmiştir. Bu sonuçlar Türk fındık çeşitlerinin kendine özgü stoma özelliklerine sahip olduğunu ve bunun çeşit tanımlamasında kullanılabileceğini göstermektedir.
\end{abstract}

Anahtar Kelimeler: Fındık; Stoma; Stoma yoğunluğu; Stoma indeksi 


\section{Introduction}

Stomata are microscopic openings or pores providing connection between inner tissues and external environment, and they are present in all organs of plants except in the roots (Zhatkanbaev \& Khazhmuratov 1982; Hoover 1986). However the most of the stomata are found in the leaves. Location of stomata on leaves differs among plants. Stomata can be located in both the upper and the lower leaf surfaces (amphistomatous), but in most of the plants they are found in the lower surface only (hypostomatous) while some others may have in the upper surface (hyperstomatous) with fewer stomata (Iotsova-Baurenska 1975; Brownlee 2001; Çağlar et al 2004). In addition, anatomy and the number of stomata may vary among plant species, varieties and even clones (Düring 1980; Aksoy \& Misırlı 1994; Çağlar et al 2004; Sohie et al 2008). Growing conditions and ecological factors may generate some differences in stoma anatomy and the number. Stomata play significant role in regulation of plant-water relationships that almost $85-90 \%$ of water loss occurs through stomata (Yentür 1984). Therefore, it is of significant importance to know anatomy, number and location of stomata on leaves for crop production and maintaining plant water balance. Although anatomy and the number of stomata in apple, chestnut, walnut, grape, cherry, mahaleb cherry and fig are well documented there is no published paper available on hazelnuts (Aksoy \& Misırlı 1994; Marasalı \& Aktekin 2003; Çağlar et al 2004; Gülen et al 2004; Mert et al 2009). Stomatal features have significant effects on certain physiological processes such as photosynthesis, transpiration, plant photosynthetic activities and responses to environmental factors as reported on field crops such as rice and wheat (Ohsinu et al 2007; Yousufzai et al 2009; Arminian et al 2010; Sarwar et al 2013). Significant positive correlations between stomatal features with yield and yield related traits were observed in some of these studies and these relationships were used as criteria in selection of drought resistant and high yielding varieties.

Turkey is located in the origin and gene center of hazelnut and it is the largest hazelnut producer supplying approximately $70 \%$ of world hazelnut production and trade. Turkish hazelnut cultivars have a unique quality attributes that they are always demanded by importers. Hazelnuts are grown in Eastern and Western Black Sea regions since it requires specific climatical conditions. More than 18 cultivars exist but mostly several of them such as Tombul, Foşa and Palaz are heavily produced. Determination of stomatal features of Turkish hazelnut cultivars is of considerable importance in examination of relationships between stomatal features and important physiological activities such as photosynthesis, water loss, plant growth, yield related traits and yield in hazelnut production. The aim of this study was to determine stomatal density and distribution in leaves of 18 Turkish hazelnut cultivars.

\section{Material and Methods}

This study was carried out in Ordu in 2010. The leaf samples of 18 cultivated hazelnut cultivars located in collection plot of Hazelnut Research Station in Giresun, Turkey were used as plant material. The province of Giresun runs in the second place in hazelnut production and is situated between $40^{\circ} 53^{\prime} \mathrm{N}$ and $38^{\circ} 19^{\prime} \mathrm{E}$, on the Eastern Black Sea coastal area. Sampled cultivars were Ac1, Allahverdi, Cavcava, Çakıldak, Foşa, İncekara, Kan, Kalınkara, Karafındık, Kargalak, Kuş, Mincane, Palaz, Sivri, Tombul, Uzunmusa, Yassı Badem and Yuvarlak Badem.

The leaf samples were collected from the $3^{\text {rd }}$ node of one-year old shoots on the branches at the same age from different directions of the plants in the morning hours when the number of open stomata was maximum in July. The leaf samples were kept in $70 \%$ ethanol until the investigations were made. Leaf surface cross-section method was used for studying stomatal density and distribution. Superficial-sections were made at the lower and upper epidermis of the leaf from the right and left side of the main vessel. Four sections are made for each leaf. These sections were placed on a slide with distilled water and then covered with lamellae (Cali 2009). The length $(\mu \mathrm{m})$ and width $(\mu \mathrm{m})$ of at least one stoma was measured on each section, thereby 80 or more stomata were measured for each cultivar. The 
number and size of stomata was determined on the microscope at of 40x10 magnifications using ocular micrometer. The number of stomata and epidermal cells in a unit area $\left(1 \mathrm{~mm}^{2}\right)$ was determined and stoma index (SI) as percent was calculated (Meidner \& Mainsfield 1969) by following formula;

$$
\begin{aligned}
& \mathrm{SI}=\frac{\text { Number of stomata per unit area }}{\text { Number of stomata per unit area }+} \text { X } 100 \\
& \text { Number of epidermal cells per unit area }
\end{aligned}
$$

The experimental design was a completely randomized design with 4 replications, one plant in each replication which represented by 5 leaves. The data were subjected to Analysis of Variance using MINITAB statistical package and mean separation by Least Significant Difference (LSD) test $(\mathrm{P} \leq 0.05)$.

\section{Results and Discussion}

Our investigations showed that there was no stoma on upper leaf surface in cultivated hazelnuts. Stomata were detected only in the lower surface of the leaves that hazelnut cultivars have hypostomatic type of stoma distribution on leaves. A picture of a stoma cell in a leaf of Sivri cultivar is given in Figure 1. In pistachio, stomata exist both in upper and lower leaf epidermis (Çağlar \& Tekin 1999).

There were significant differences $(\mathrm{P} \leq 0.05)$ in the number of stomata per unit leaf surface area, stoma index $(\%)$, the length $(\mu \mathrm{m})$ and width $(\mu \mathrm{m})$ of stomata among the cultivars (Table 1).

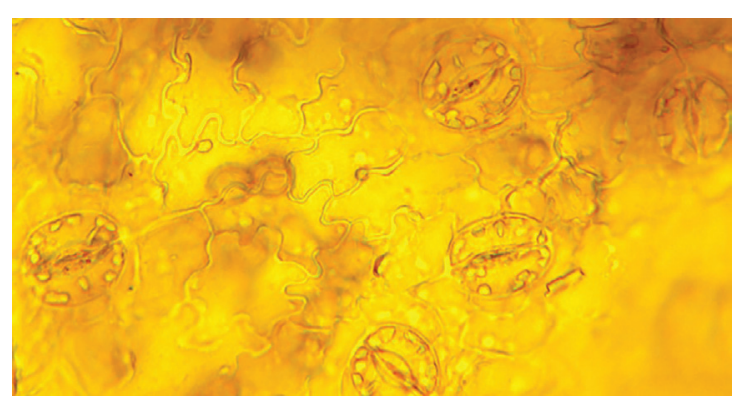

Figure 1- A picture of stomata in the leaves of Sivri hazelnut cultivar

Şekil 1- Sivri findık çeşidinin yapraklarındaki stomaların görünümü

Table 1- The number of stomata, stoma width, stoma length, stoma index and the number of epidermal cells in the leaves of 18 Turkish hazelnuts cultivars

Çizelge1- 18 Türk findık çeşitlerinin yapraklarındaki stoma sayısı, stoma genişliği, stoma uzunluğu, stoma indeksi

\begin{tabular}{|c|c|c|c|c|c|}
\hline Cultivars & $\begin{array}{c}\text { Number of stomata } \\
\mathrm{mm}^{-2}\end{array}$ & $\begin{array}{l}\text { Stoma width } \\
\text { ( } \mu \mathrm{m})\end{array}$ & $\begin{array}{c}\text { Stoma length } \\
(\mu \mathrm{m})\end{array}$ & Stoma index (\%) & $\begin{array}{c}\text { Number of epidermal } \\
\text { cells } \mathrm{mm}^{-2}\end{array}$ \\
\hline Ac1 & $113.64 \mathrm{~b}^{*}$ & $17.78 \mathrm{~g}^{*}$ & $22.78 \mathrm{~g}^{*}$ & 14.28 def* & 681.0 \\
\hline Allahverdi & $95.25 \mathrm{~g}$ & $20.47 \mathrm{~d}$ & $25.86 \mathrm{c}$ & $14.36 \mathrm{de}$ & 681.0 \\
\hline Cavcava & $98.32 \mathrm{ef}$ & $20.00 \mathrm{e}$ & $25.00 \mathrm{~d}$ & $12.51 \quad 1$ & 681.0 \\
\hline Cakıldak & $106.58 \mathrm{~d}$ & $20.00 \mathrm{e}$ & $24.02 \mathrm{e}$ & $15.82 \mathrm{~b}$ & 681.0 \\
\hline Fosa & $94.38 \mathrm{gh}$ & 19.70 ef & $24.36 \mathrm{e}$ & $14.25 \mathrm{def}$ & 681.0 \\
\hline İncekara & $107.34 \mathrm{~d}$ & $20.02 \mathrm{e}$ & $24.25 \mathrm{e}$ & $15.87 \mathrm{~b}$ & 681.0 \\
\hline Kalınkara & $83.08 \mathrm{k}$ & $20.00 \mathrm{e}$ & $25.00 \mathrm{~d}$ & $10.55 \mathrm{k}$ & 681.0 \\
\hline Kan & $96.45 \mathrm{fg}$ & $21.65 \mathrm{~b}$ & $26.66 \mathrm{~b}$ & $14.52 \mathrm{~d}$ & 567.0 \\
\hline Karafindık & 91.48 ij & 20.00 e & $25.17 \mathrm{~d}$ & $13.95 \mathrm{fg}$ & 681.0 \\
\hline Kargalak & $92.11 \mathrm{~h} 1$ & $20.65 \mathrm{~d}$ & $25.68 \mathrm{c}$ & $14.07 \mathrm{ef}$ & 567.0 \\
\hline Kus & $90.80 \quad \mathrm{ij}$ & $20.00 \mathrm{e}$ & $25.00 \mathrm{~d}$ & $11.66 \mathrm{j}$ & 681.0 \\
\hline Mincane & $99.60 \mathrm{e}$ & $21.13 \mathrm{c}$ & $23.65 \mathrm{f}$ & $14.91 \mathrm{c}$ & 567.0 \\
\hline Palaz & $91.45 \mathrm{ij}$ & 19.92 ef & $24.88 \mathrm{~d}$ & 14.03 efg & 567.0 \\
\hline Sivri & $117.73 \mathrm{a}$ & $17.00 \mathrm{~h}$ & $22.00 \mathrm{~h}$ & $17.15 \mathrm{a}$ & 567.0 \\
\hline Tombul & $83.31 \mathrm{k}$ & $19.67 \mathrm{f}$ & $24.80 \mathrm{~d}$ & $13.21 \mathrm{~h}$ & 567.0 \\
\hline Uzunmusa & $96.28 \mathrm{fg}$ & $20.02 \mathrm{e}$ & $25.02 \mathrm{~d}$ & $12.30 \quad 1$ & 681.0 \\
\hline Yassı Badem & $88.96 \mathrm{j}$ & $22.61 \mathrm{a}$ & $27.45 \mathrm{a}$ & $13.72 \mathrm{~g}$ & 681.0 \\
\hline Yuvarlak Badem & $110.58 \mathrm{c}$ & $20.00 \mathrm{e}$ & $25.00 \mathrm{~d}$ & 14.07 ef & 681.0 \\
\hline Mean & 97.63 & 20.02 & 24.81 & 13.96 & 643.0 \\
\hline LSD & 2.46 & 0.26 & 0.34 & 0.29 & n.s \\
\hline
\end{tabular}
ve epidermal hücre sayısı

*, different letters in the same column indicates significant differences $(\mathrm{P} \leq 0.05)$ 
The average number of stomata was $97.63 \mathrm{~mm}^{-2}$ among the cultivars. Kalınkara had the highest number $\left(83.03 \mathrm{~mm}^{-2}\right)$ while Sivri had the lowest $\left(117.73 \mathrm{~mm}^{-2}\right)$. Ac1 and Yuvarlak Badem had high stomata numbers $\left(113.64 \mathrm{~mm}^{-2}\right.$ and 110.58 $\mathrm{mm}^{-2}$, respectively). The most significant Turkish hazelnut cultivar Tombul had one of the lowest numbers $\left(83.31 \mathrm{~mm}^{-2}\right)$. Çağlar et al (2004) reported that stomatal density in walnut (Juglans regia L.) genotypes varied between 120 and $217 \mathrm{~mm}^{-2}$. Mert et al (2009) showed that the number of stomata was within the range of $344.21-619.36 \mathrm{~mm}^{-2}$ in apple cultivars which were grafted on different rootstocks. In pistachio cultivars, stomatal density on the upper and the lower leaf surface epidermis varied between 114 and $151 \mathrm{~mm}^{-2}$, and 171 and 221 $\mathrm{mm}^{-2}$, respectively (Çağlar \& Tekin 1999). Stomata number in cherry and apple cultivars ranged from 202.38 to 469.39 and from 442.18 to 547.62 , respectively (Gülen et al 2004). Our results showed lower number of stomata on their leaves in hazelnuts which may be explained by the effect of crop species on the number of stomata (Aksoy \& Misirlı 1994; Çağlar et al 2004). In general, number of stomata might vary within species, varieties and even types, and according to growing conditions. Particularly, altitude has very significant effect that the number of stomata increases as altitude increases from the sea level (Iotsova-Baurenska 1975; Çağlar et al 2004). Similarly, water deficit in the soil and heavy light conditions may result in an increase in the number of stomata. Thus, lower number of stomata in hazelnuts might also be under effect of environmental factors as the hazelnut plants sampled in this study were grown at low altitude, basically at the sea level, under lower light conditions with prolonged rainfall and cloudy weathers which is typical characteristics of the Black Sea Region. It would be interesting to see the change of stomata number in hazelnuts across elevations $(0-750 \mathrm{~m})$ and from eastern to western regions in Black Sea Region.

There were significant differences $(\mathrm{P} \leq 0.05)$ in the stoma width among hazelnut cultivars. The average stoma width was $20.02 \mu \mathrm{m}$ and it ranged from $17.00 \mu \mathrm{m}$ (Sivri) to $22.61 \mu \mathrm{m}$ (Yass1 Badem) among the cultivars (Table 1). Kan $(21.65 \mu \mathrm{m})$ and Mincane $(21.13 \mu \mathrm{m})$ followed Yass1 Badem. These results are in agreement with the measurements of $17.5-22.5 \mu \mathrm{m}$ in cherry and 20.83-22.5 $\mu \mathrm{m}$ in apple cultivars (Gülen et al 2004). The leaves with larger stomata had higher photosynthetic rate than the leaves with smaller stomata as it was shown in rice (Chandra \& Das 2000). In general, the leaves of cultivars with high stomatal density had narrower stoma (Iotsova-Baurenska 1975; Mert et al 2009). Our results, in general, may support this statement that we obtained negative correlation coefficients between number of stomata and stoma diameter except Kuş $(r=0.032)$, Mincane $(r=0.129)$ and Uzunmusa $(r=0.192)$ cultivars. No correlation was detected in Tombul (Table 2). Among the cultivars, correlation coefficients were calculated between $\mathrm{r}=$ -0.375 (Kan) and $r=0.192$ (Uzunmusa), but these coefficients are considered low by Düzgüneş et al (1983). Regardless of cultivars, the correlation coefficient was $r=-0380$ for hazelnuts.

Table 2- Correlation coefficients for stomata number (SN) with stoma width (SW) and stoma length (SL) in 18 Turkish hazelnut cultivars

Çizelge 2- 18 Türk Findık çeşidinde stoma saylsı $(S N)$ ile stoma genişliği (SW) ve stoma uzunluğu (SL) arasindaki korelasyon katsayıları

\begin{tabular}{lcc}
\hline Cultivars & $S N-S W(r)$ & $S N-S L(r)$ \\
\hline Acı & -0.283 & -0.206 \\
Allahverdi & -0.126 & 0.033 \\
Cavcava & -0.185 & -0.229 \\
Çakıldak & -0.052 & -0.065 \\
Foşa & -0.353 & -0.153 \\
İncekara & -0.080 & -0.027 \\
Kalınkara & -0.009 & -0.294 \\
Kan & -0.375 & -0.451 \\
Karafindık & -0.137 & -0.002 \\
Kargalak & -0.022 & 0.024 \\
Kuş & 0.032 & 0.032 \\
Mincane & 0.129 & 0.129 \\
Palaz & -0.104 & -0.104 \\
Sivri & -0.071 & -0.071 \\
Tombul & 0.000 & 0.000 \\
Uzunmusa & 0.192 & 0.192 \\
Yassi Badem & -0.161 & -0.161 \\
Yuvarlak Badem & -0.005 & -0.005 \\
\hline General & -0.380 & -0.407 \\
\hline
\end{tabular}


Stoma length significantly changed $(\mathrm{P} \leq 0.05)$ among the cultivars (Table 1). The average stoma length was $24.81 \mu \mathrm{m}$ and the range was between $22.00 \mu \mathrm{m}$ (Sivri) and $27.45 \mu \mathrm{m}$ (Yass1 Badem). The cultivar Yass1 Badem appeared to have the largest stomata. Çağlar et al. (2004) reported 14$18 \mu \mathrm{m}$ stoma length in walnuts collected from Kahramanmaraş province, but $21-28 \mu \mathrm{m}$ in walnuts collected from Hatay province. We obtained a negative correlation $(r=-0.407)$ between stoma density and stoma size for hazelnuts (Table 2). The cultivars had between -0.451 (Kan) and 0.192 (Uzunmusa) correlation coefficients. Similarly, a negative correlation between stoma density and stoma size in walnut and apple were reported by researchers (Çağlar et al 2004; Mert et al 2009). The correlation coefficients for apple cultivars were $r=-0.805$ in Vista Bella, $r=-0.860$ in Fuji, $r$ $=-0.205$ in Granny Smith and $r=0.659$ in Mondial Gala (Mert et al 2009). Stoma size is related to specific stomatal conductance which is closely related to leaf photosynthesis leading to higher yield in hybrid cultivars in rice (Ohsuni et al 2007). In similar studies, significant positive correlations between grain yield and number, length and breadth of stomatal apparatus in rice and wheat was shown (Yousufzai et al 2009; Arminian et al 2010; Sarwar et al 2013). These researchers concluded that, number and size of the stomata were directly related with photosynthetic activities and higher photosynthetic activities in turn were related to higher yield.

Significant differences were found for stoma index among the cultivars $(\mathrm{P} \leq 0.05)$. The average SI was $13.96 \%$ and it varied between 10.55 and $17.15 \%$ (Table 1). Sivri had the highest stoma index $(17.15 \%)$, followed by İncekara $(15.87 \%)$ and Mincane (14.91\%). The lowest SI $(10.55 \%)$ was recorded in Kalınkara. These results indicate a large genetic variation among the cultivars in terms of stoma index. This may be explained with the differences in water uptake capacity, light requirement level and plant growth speed (Warrit et al 1980; Kara \& Özeker 1999; Mert et al 2009).
There were no significant differences among hazelnut cultivars for the total number of epidermal cells per unit area in leaf surface which was between 567.00 and 681.00 per $\mathrm{mm}^{2}$.

\section{Conclusions}

The present study revealed that stomata are located in the lower surface of the leaves in hazelnuts. There were significant differences in number of stomata and stoma size among 18 cultivated hazelnut cultivars. These differences may be useful in varietal identification. Currently, there is no information on effect of stomatal features on photosynthesis, water loss, plant growth and yield in hazelnuts. This might be a future challenge.

\section{References}

Aksoy U \& Misırl1 A (1994). Sarılop incir klonlarının yaprak özellikleri ve stoma dağılımı üzerinde araştırmalar. Ege Üniversitesi Ziraat Fakültesi Dergisi 31(1-2): 57-63

Aminian R, Mohammadi S, Hoshmand SA\& Khodambashi $M(2010)$. The genetic analysis of stomatal frequency and size, stomatal conductance, photosynthetic rate and yield in wheat (Triticum aestivum L.) using substitution lines series. Wheat Information Service 110: $25-34$

Brownlee C (2001). The long and short of stomatal density signals. Trends in Plant Science 6: 41-442

Chandra K \& Das A K (2000). Correlation and interaction of physiological parameters in rice under rainfed transplanted condition. Journal of Research Assam Agriculture University 19: 251-254

Cali İ Ö (2009). The effect of fosetyl-Al application on stomata in tomato (Lycopersicon esculentum Mill.) plant. Journal of Plant Breeding and Crop Science 1(3): $45-48$

Çağlar S \& Tekin H (1999). Farklı Pistacia anaçlarına aşı1ı antepfıstığ 1 çeşitlerinin stoma yoğunlukları. Turkish Journal of Agriculture and Forestry 23(5): 1029-1032

Çağlar S, Sütyemez M \& Bayazit S (2004). Seçilmiş bazı ceviz (Juglans regia) tiplerinin stoma yoğunlukları. Akdeniz Üniversitesi Ziraat Fakültesi Dergisi 17(2): 169-174 
Düring H (1980). Stomatafrequenz bei Blattern von VitisArten und -Sorten, Vitis 19: 91-98

Düzgüneş O, Kesici T \& Gürbüz F (1983). İstatistik Metotları I. Ankara Üniversitesi Ziraat Fakültesi Yayın No: 861, Ankara

Gülen H, Köksal N \& Eriş A (2004). Farklı anaçlar üzerine aşılı bazı kiraz ve elma çeşitlerinde stoma yoğunluğu ve stoma boyutları. Bahçe 33(1-2): 1-5

Hoover W S (1986). Stomata and stomata clusters in Begonia: ecological response in two Mexican species. Biotropica 18(1): 16-21

Iotsova-Baurenska N (1975). Stomatal numbers and size in Juglans regia in relation to ecological conditions. Fitologiya 1: 19-24

Kara S \& Özeker E (1999). Farklı anaçlar üzerinde aşılı yuvarlak çekirdeksiz üzüm çeşidinin yaprak özellikleri ve stoma dağılımı üzerinde araştırmalar. Anadolu Journal of Agriculture 9(1): 76-85

Marasalı B \& Aktekin A (2003). Sulanan ve sulanmayan bağ koşullarında yetiştirilen üzüm çeşitlerinde stoma sayısının karşılaştırılması. Tarım Bilimleri Dergisi 9(3): $370-372$

Meidner H \& Mansfield T A (1969). Physiology of stomata. Mc Graw-Hill, Newyork, USA

Mert C, Barut E \& Uysal T (2009). Farklı anaçlar üzerine aşılı elma çeşitlerinin stoma morfolojilerinin araştırılması. Tarım Bilimleri Araştırma Dergisi 2(2): 61-64
Ohsuni A, Kanemura T, Homma K, Horie T \& Shiraiwa T (2007). Genotypic variation of stomatal conductance in relation to stomatal density and length in rice (Oryza sativa L.). Plant Production Science 10: 322-328

Sarwar A K M, Golam Abdul Karim A \& Masud Rana S M A (2013). Influence of stomatal characteristics on yield and yield attributes of rice. Journal of Bangladesh Agricultural University 11(1): 47-52

Sophie Y D, Marron N, Barbra K \& Reinhart C (2008). Genetic Variation of Stomatal Traits and Carbon Isotope Discrimination in Two Hybrid Poplar Families (Populus deltoides 'S9-2' $\times$ P. nigra 'Ghoy' and $P$. deltoides 'S9-2' $\times$ P. trichocarpa 'V24'). Annals of Botany 102: 399-407

Warrit B, Landsberg J J \& Thorpe M R (1980). Responses of apple leaf stomata to environmental factors. Plant, Cell and Environment 3:13-22

Yentür S (1984). Bitki Anatomisi. İstanbul Üniversitesi Fen Fakültesi Yayınları İstanbul, No: 191, s. 89-105

Yousufzai M N K, Siddiqui K A \& Soomro A Q (2009). Flag leaf stomatal frequency and its interrelationship with yield and yield components in wheat (Triticum aestivum L.). Pakistan Journal of Botany 41: 663-666

Zhatkanbaev Z \& Khazhmuratov M K (1982). Some Anatomical-Physiological Characteristics of Apple Trees in Zailiiskii-Alatau (Nothern Tian-Shan). 1 Vsesoyuznaya Konferentsiya po Anatomi Rastenii, Leningrad, 59 